\title{
Effects of High Stimulus Frequencies on SEPs of Patients with Neuro-Behcet's Disease
}

\author{
Hande Turker, Nilgun Cengiz, Handan Akar, Musa K. Onar, Onder Us
}

\begin{abstract}
Background: Behcet's disease is a multisystemic vascular inflammatory disorder of unknown origin. It is relatively rare and central nervous system involvement is seen in $5 \%$ of affected individuals. Somatosensory evoked potentials (SEPs) can provide information that shows the presence of clinically unsuspected lesions in the central nervous system of these patients. However, the effects of changing the stimulus frequencies on latencies of SEP potentials and central conduction time (CCT) in patients with neuroBehcet's disease (NB) have not been studied yet. In this study, our aim was to reveal these effects to investigate whether the change of stimulus frequencies could be of convenient use in obtaining more accurate CCT estimations in SEP studies of these patients. Methods: We performed median nerve SEPs of 14 patients with NB and 15 healthy volunteers. We changed the stimulus frequency: $2 \mathrm{~Hz}$, $4 \mathrm{~Hz}$, $6 \mathrm{~Hz}$ and $9 \mathrm{~Hz}$ in successive recordings and statistically compared the changes on SEP potentials and peak and onset CCT in the neuroBehcet (NB) group and the normal group. Results: Our results indicated that the onset CCT values of the NB group were higher than the normal group at $4 \mathrm{~Hz}$ and $9 \mathrm{~Hz}$ stimulations. However, the comparison of peak CCT in the NB group and the normal group did not show any statistically meaningful differences at all stimulation frequencies. Conclusion: Onset CCT has not been measured before in former SEP studies of patients with NB. We highly recommend measuring onset CCT at higher stimulation frequencies in order to reveal central conduction time pathologies in these patients.
\end{abstract}

RÉSUMÉ: Effets de stimulus de hautes fréquences sur les PÉSs de patients présentant une maladie de Behcet avec atteinte neurologique. Contexte : La maladie de Behcet est une maladie inflammatoire vasculaire multisystémique d'étiologie inconnue. C'est une maladie relativement rare et le système nerveux central est atteint chez $5 \%$ des cas. Les potentiels évoqués somesthésiques (PÉSs) peuvent démontrer chez ces patients la présence de lésions du système nerveux central qui sont silencieuses au point de vue clinique. Cependant, on n'a jamais étudié les effets de changements des fréquences de stimulation sur les latences des PÉSs et sur le temps de conduction central (TCC) chez les patients atteints de la maladie de Behcet qui ont une atteinte neurologique (MBN). Le but de cette étude était de démontrer ces effets afin de déterminer si un changement de fréquence du stimulus pouvait être utilisé pour obtenir des estimations TCC plus exactes dans les études des PÉSs chez ces patients. Méthodes : Nous avons évalué les PÉSs au niveau du nerf médian chez 14 patients atteints de MBN et 15 témoins en bonne santé. Nous avons varié la fréquence du stimulus, soit $2 \mathrm{~Hz}$, $4 \mathrm{~Hz}$, $6 \mathrm{~Hz}$ et $9 \mathrm{~Hz}$, lors d'enregistrements successifs et nous avons comparé par analyse statistique les changements observés au niveau des potentiels PÉSs ainsi qu'au niveau du pic et du délai d'apparition du TCC dans le groupe atteint de MBN et le groupe témoin. Résultats : Nos résultats indiquent que les valeurs du délai d'apparition du TCC du groupe MBN étaient plus élevées que celles du groupe témoin pour les stimulations à $4 \mathrm{~Hz}$ et $9 \mathrm{~Hz}$. Cependant, il n'y avait pas de différence significative au point de vue statistique entre le pic du TCC chez le groupe MBN et le groupe témoin à différentes fréquences de stimulation. Conclusion: Le délai d'apparition du TCC n'a pas été mesuré antérieurement dans les études des PÉSs chez les patients atteints de MBN. Nous recommandons fortement de mesurer le délai d'apparition du TCC à des fréquences de stimulation plus élevées afin de détecter des pathologies du temps de conduction central chez ces patients.

Can. J. Neurol. Sci. 2006; 33: 387-393

The reported frequency of neurological involvement among patients with Behcet's disease ranges from 2.2 to $49 \% .^{1}$ However, larger series have shown a rate of approximately $5 \% .^{2}$ Paraparesis and quadriparesis, pseudobulbar palsy, cranial nerve palsies, cerebellar ataxia and aseptic meningoencephalitis are the most common presentations. ${ }^{3}$ The disease mostly involves the diencephalon, brain stem and spinal cord. ${ }^{3}$ Abnormal somatosensory evoked potentials can provide sensitive information that shows the presence of subclinical lesions in the central nervous system of Behcet patients. ${ }^{4}$ Mild slowing of central conduction time was one of the predominant somatosensory evoked potential (SEP) abnormalities in eight patients with neuro-Behcet $(\mathrm{NB})$ in a studv bv Stigsbv et al. ${ }^{5}$
Changes of stimulation frequency of SEPs may alter the latency and amplitudes of SEP potentials in normal people. .-8 $^{6-}$ Therefore, there may also be changes in the central conduction time ${ }^{6}$ Cord-cortex conduction time, sometimes referred to as the

From the Faculty of Medicine, Department of Neurology (HT, NC, HA, MKO), Ondokuzmayis University, Samsun; Faculty of Medicine, Department of Neurology (OU), Marmara University, Istanbul, Turkey.

Received January 4, 2006. ACCEPTED IN FinAl FORM SEPTEMber 2, 2006 Reprint requests to: Hande Turker, Ondokuzmayis University, Faculty of Medicine, Department of Neurology, 55139 Samsun, Turkey. 
central conduction time (CCT) is usually calculated by the peakto-peak N13-N20 interval. The CCT can also be evaluated by measuring the interval between N13 and N20 onset latencies. ${ }^{9}$ It is not known whether the change of stimulus frequency will affect SEP parameters in people with various diseases of the central nervous system that affect central conduction time.

In this study, our aim was to reveal the effects of changing the stimulus frequencies on latencies of median nerve SEP potentials and peak and onset central conduction times in patients with NB. We also tried to investigate whether the change of stimulus frequencies could be of convenient use in obtaining more accurate results in SEP studies of these patients.

\section{Materials AND Methods}

\section{Materials}

Our study group consisted of 14 patients with NB seen in our department over a two year period between 2003 and 2005. All patients fulfilled the diagnostic criteria of ISGBD (International
Study Group for Behcet's Disease - $1990 .{ }^{10}$ In addition, they all had neurological symptoms and signs consistent with neuroBehcet's disease (Table 1 summarizes the clinical, laboratory and imaging features of the patient group). Eleven patients were males and three patients were females. Their mean age was $33.57 \pm 8.12$ years ranging from 22 to 45 years. Fifteen normal healthy people (11 males and 4 females) volunteered for the control group. Their mean age was $33.46 \pm 10.9$ years, ranging from 20 to 46 years. Body heights and arm lengths of every patient and normal person were also measured. Somatosensory evoked potential studies by median nerve stimulation on both upper extremities of patients and controls were performed and 58 extremities were studied. Each SEP recording was performed four times for four different stimulation frequencies on each extremity and thus 232 SEP recordings were performed. Beforehand each patient and normal control had nerve conduction tests and needle electromyography (EMG) in order to exclude peripheral neuropathy and/or mononeuropathies that could affect the results of the study. On the basis of EMG results,

Table 1: Summary of clinical, laboratory and imaging features in the NB group

\begin{tabular}{|c|c|c|c|c|}
\hline $\mathbf{P}$ & $\begin{array}{l}\text { Agel } \\
\text { Gender }\end{array}$ & Neurological symptoms and signs & Diagnostic findings & CCT in median nerve SEP \\
\hline 1 & $41 / \mathrm{M}$ & Right hemiparesis, bulbar signs, bilateral cerebellar signs & $\begin{array}{l}\text { Cranial MRI: T2W hyperintense lesions of bilateral mesencephalon, pons, } \\
\text { cerebellar peduncles and left thalamus }\end{array}$ & $\begin{array}{l}\text { Peak and onset } \mathrm{CCT}= \\
\mathrm{N} \text { at } 2 \mathrm{~Hz}\end{array}$ \\
\hline 2 & $41 / \mathrm{M}$ & $\begin{array}{l}\text { Paralysis of vertical gaze, left hemiparesis, sequel of } \\
\text { right hemiparesis, cerebellar signs, tactile agnosia }\end{array}$ & $\begin{array}{l}\text { Cranial MRI: T2W hyperintense lesions of left mesencephalon, pons, cerebellar } \\
\text { peduncles, right thalamus and posterior limbs of both internal capsules }\end{array}$ & $\begin{array}{l}\text { Peak and onset } \mathrm{CCT}= \\
\mathrm{N} \text { at } 2 \mathrm{~Hz}\end{array}$ \\
\hline 3 & $45 / M$ & Dysphasia & $\begin{array}{l}\text { Cranial MRI: T2W hyperintense lesions of right parietal subcortical and multiple } \\
\text { periventricular lesions }\end{array}$ & $\begin{array}{l}\text { Peak and onset CCT } \\
\text { prolonged at } 2 \mathrm{~Hz}\end{array}$ \\
\hline 4 & $41 / \mathrm{M}$ & Recurrent headaches, vomiting & Normal CSF findings, normal cranial MRI & $\begin{array}{l}\text { Peak } \mathrm{CCT}=\mathrm{N} \text {, onset } \mathrm{CCT} \\
\text { prolonged at } 2 \mathrm{~Hz}\end{array}$ \\
\hline 5 & $29 / M$ & Bilateral cerebellar signs & Cranial MRI: T2W hyperintense lesions of right cerebellar peduncle & $\begin{array}{l}\text { Peak } \mathrm{CCT}=\mathrm{N} \text {, onset } \mathrm{CCT} \\
\text { prolonged at } 2 \mathrm{~Hz}\end{array}$ \\
\hline 6 & $33 / \mathrm{M}$ & $\begin{array}{l}\text { Increased deep tendon reflexes, hypoesthesia between } \\
\text { T6 and T12 levels, ataxic gait }\end{array}$ & $\begin{array}{l}\text { Normal cranial MRI and thoracic MRI. Cervical MRI: T2W hyperintense lesions of } \\
\text { spinal cord at C } 3 \text { and } C 6 \text { levels }\end{array}$ & $\begin{array}{l}\text { Peak and onset } \mathrm{CCT}= \\
\mathrm{N} \text { at } 2 \mathrm{~Hz}\end{array}$ \\
\hline 7 & $23 / \mathrm{M}$ & $\begin{array}{l}\text { Paraparesis, right hemihypoesthesia excluding face, } \\
\text { spasticity of both lower extremities, increased deep } \\
\text { tendon reflexes, pyramidal ataxia }\end{array}$ & $\begin{array}{l}\text { Cranial MRI: Normal, Cervical MRI: T2W hyperintense lesions of spinal cord at C4 } \\
\text { level (Isolated lesion of cervical spinal cord) }\end{array}$ & $\begin{array}{l}\text { Peak and onset } \mathrm{CCT}= \\
\mathrm{N} \text { at } 2 \mathrm{~Hz}\end{array}$ \\
\hline 8 & $38 / F$ & Dysarthria and right hemiparesis & $\begin{array}{l}\text { Cranial MRI: Contrast enhanced lesions of left lentiform nucleus, left thalamus, left } \\
\text { posterior limb of internal capsule and left pons }\end{array}$ & $\begin{array}{l}\text { Peak and onset } \mathrm{CCT}= \\
\mathrm{N} \text { at } 2 \mathrm{~Hz}\end{array}$ \\
\hline 9 & $24 / \mathrm{M}$ & $\begin{array}{l}\text { Signs of cognitive impairment, right Achilles clonus, } \\
\text { symmetrically increased deep tendon reflexes }\end{array}$ & $\begin{array}{l}\text { Cranial MRI: T2W hyperintense multiple lesions of pons (No contrast enhancement } \\
\text { on T1W images) }\end{array}$ & $\begin{array}{l}\text { Peak } \mathrm{CCT}=\mathrm{N} \text {, onset } \mathrm{CCT} \\
\text { prolonged at } 2 \mathrm{~Hz}\end{array}$ \\
\hline 10 & $26 / \mathrm{M}$ & Quadriparesis, bedridden state & $\begin{array}{l}\text { Cervical MRI: Normal Cranial MRI: T2W hyperintense multiple lesions of bilateral } \\
\text { periventricular zones } \\
\text { VEP: Bilateral prolonged latencies of cortical P100 waves }\end{array}$ & $\begin{array}{l}\text { Peak } \mathrm{CCT}=\mathrm{N} \text {, onset } \mathrm{CCT} \\
\text { prolonged at } 2 \mathrm{~Hz}\end{array}$ \\
\hline 11 & $43 / \mathrm{M}$ & $\begin{array}{l}\text { Right hemiparesis, right hemihypoesthesia including } \\
\text { face, increased deep tendon reflexes, Babinsky sign and } \\
\text { Achilles clonus bilaterally positive }\end{array}$ & $\begin{array}{l}\text { Cranial MRI: T2W hyperintense lesions of bilateral mesencephalon, pons, bilateral } \\
\text { thalamus and right caudate nucleus }\end{array}$ & $\begin{array}{l}\text { Peak and onset } \mathrm{CCT} \\
\text { prolonged at } 2 \mathrm{~Hz}\end{array}$ \\
\hline 12 & $22 / F$ & $\begin{array}{l}\text { Generalised tonic clonic seizures, increased deep tendon } \\
\text { reflexes }\end{array}$ & $\begin{array}{l}\text { Cranial MRI: Bihemispheric cortical and subcortical ischemia of both occipital lobes } \\
\text { Contrast series: Bilateral pial contrast enhancements } \\
\text { EEG: Epileptiform activity of both frontocentrotemporal regions }\end{array}$ & $\begin{array}{l}\text { Peak } \mathrm{CCT}=\mathrm{N} \text {, onset } \mathrm{CCT} \\
\text { prolonged at } 2 \mathrm{~Hz}\end{array}$ \\
\hline 13 & $28 / M$ & Bilateral papilla oedema & $\begin{array}{l}\text { Cranial MRI: Normal } \\
\text { VEP: Prolongation of left P100 latency }\end{array}$ & $\begin{array}{l}\text { Peak and onset } \mathrm{CCT}= \\
\mathrm{N} \text { at } 2 \mathrm{~Hz}\end{array}$ \\
\hline 14 & $36 / F$ & Headache, diplopia, dysarthria & Cranial MRI: T2W hyperintense lesions of left lentiform nucleus and thalamus & $\begin{array}{l}\text { Peak and onset } \mathrm{CCT}= \\
\mathrm{N} \text { at } 2 \mathrm{~Hz}\end{array}$ \\
\hline
\end{tabular}

P: Patient, M: Male, F: Female, MRI: Magnetic resonance imaging, T2W: T2 weighted, T1W: T1 weighted, VEP: Visual evoked potential, EEG: Electroencehphalography, CCT: Central conduction time, N: Normal, CSF: Cerebrospinal fluid 
we excluded three patients who had polyneuropathy diagnosed electrophysiologically and the original number of 17 patients declined to 14 .

Every patient had a thorough neurological examination besides proper imaging tests (Cranial MRI and/or cervical spinal MRI). Some of the patients had also pattern visual evoked potentials (VEPs) and brain stem auditory evoked potentials (BAEPs) (Ten patients had VEPs and ten had BAEPs).

All the patients and controls signed consent forms and the procedure was explained thoroughly to all of them. Both of the groups were told that if the stimulation felt painful, the test would be stopped. All of the patients and controls could tolerate the higher stimulation frequencies.

\section{Methods}

During median nerve SEP recordings, surface electrodes were used and the impedance was kept under $5 \mathrm{k}$ ohm. All recordings were performed on Dantec Keypoint. The median nerve SEP montage included the erb channel where ipsilateral and contralateral erb points were selected as the localizations for active and reference electrodes respectively. The active electrode for the spinal channel was placed on the fifth cervical spinous process (cv5) whereas the supraglottal region on the midline was chosen as the reference point. Active electrode of the scalp channel was placed five centimetres posterior to $\mathrm{Cz}$ and seven centimetres lateral to midline, while the reference electrode was on Fz. The ground electrode was placed on the forearm.

Parameters that were compared statistically between the two groups were peak latencies of N13 and N20 potentials, onset latencies of N13 and N20 potentials and peak and onset central conduction times at $2 \mathrm{~Hz}, 4 \mathrm{~Hz}, 6 \mathrm{~Hz}$ and $9 \mathrm{~Hz}$ stimulation frequencies (The estimation of peak and onset latencies of N13 and N20 together with peak and onset CCTs are shown in Figure 1). Mean values and standard deviations of every parameter in different stimulations were calculated in both of the groups. Apart from the statistical comparison test (Student t test) that was used to compare the parameters between the NB group and the control group, additional tests (Repeated Measures ANOVA and paired samples test) were used to compare the parameters at different stimulation frequencies within the same group. Fisher's Exact Ghi-square and Student $t$ tests were used to perform statistical comparisons of age, body height, sex and arm length between the NB group and the normal group.

The electrical stimuli applied to the median nerve consisted of rectangular pulses of $0.2 \mathrm{msec}$ in duration. Sweep speed was 5 $\mathrm{ms} / \mathrm{div}$, sensitivity was $5 \mu \mathrm{v} / \mathrm{div}$ and the amplifier had a frequency band of $20 \mathrm{~Hz}-2 \mathrm{kHz}$. Stimulus frequency was changed to $2 \mathrm{~Hz}$, $4 \mathrm{~Hz}, 6 \mathrm{~Hz}$ and $9 \mathrm{~Hz}$ in each successive recording. Stimulus intensity was adjusted to the stimulus causing minimal abduction of the thumb. The number of responses elicited in each trial was 1000 and analysis time was $50 \mathrm{msec}$. Each trace was replicated at least once and superimposed in order to demonstrate the reproducibility. Peak latencies were marked at the sharpest tip of the negative potentials while onset latencies were measured from the take off point of the potential from the isoelectrical line (Figure 1).

Following median nerve stimulation, the peak CCT was calculated by subtracting the peak latency of the spinal N13 component from the peak latency of the cortical N20 potential.

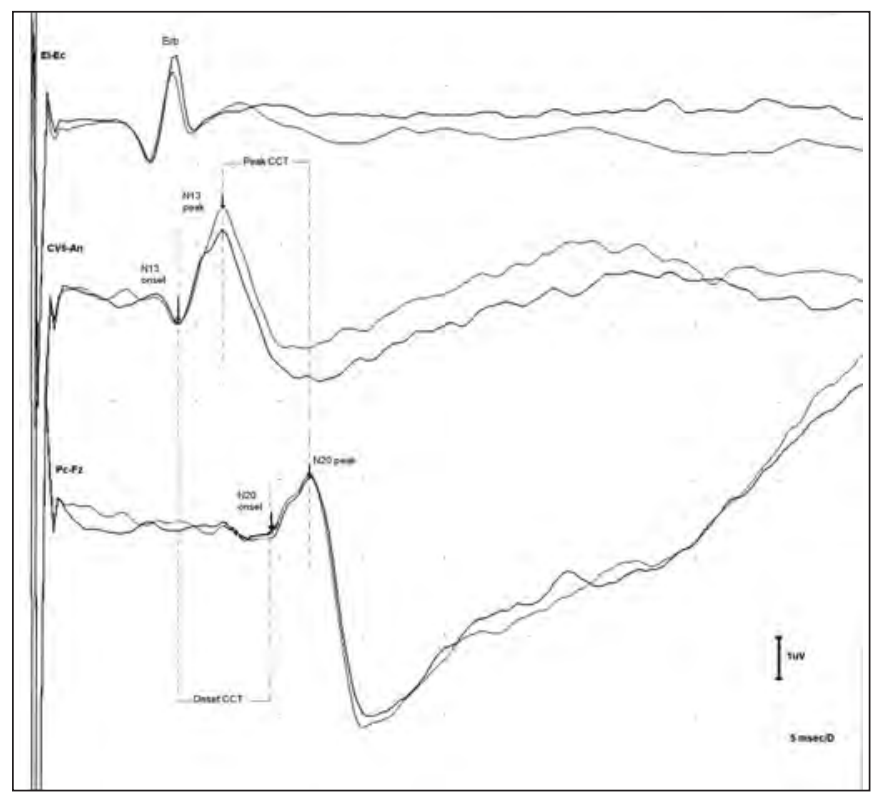

Figure 1: Onset and peak latencies of N13 and N20 potentials, peak and onset CCTs.

The onset CCT was calculated by subtracting the onset latency of spinal N13 potential from the onset latency of the cortical N20 potential (Figures 1,2).

\section{RESULTS}

Twelve patients had lesions in imaging studies. Nine of these patients had lesions that could affect CCT (64\% of all patients). Seven patients had prolonged CCT values at $2 \mathrm{~Hz}(\% 50)$, all of them had prolonged onset CCT values (\%50), only two of them had prolonged peak CCT values (14\%) and the remaining five had normal peak CCT values. Only four patients who had

Table 2: Statistical distribution of onset and peak latency values of $\mathrm{N} 13$

\begin{tabular}{|c|c|c|c|c|c|c|c|}
\hline \multirow{2}{*}{$\begin{array}{c}\text { N13 } \\
\text { onset } \\
\text { latency }\end{array}$} & $\begin{array}{l}\text { Patient } \\
\text { group }\end{array}$ & $\begin{array}{l}\text { Control } \\
\text { group }\end{array}$ & \multirow{2}{*}{$\begin{array}{c}\text { t test; } \\
\quad p\end{array}$} & \multirow{2}{*}{$\begin{array}{c}\text { N13 } \\
\text { peak } \\
\text { latency }\end{array}$} & \multirow{2}{*}{$\begin{array}{c}\begin{array}{c}\text { Patient } \\
\text { group }\end{array} \\
\text { Mean }_{ \pm} \text {SD }\end{array}$} & \multirow{2}{*}{$\begin{array}{c}\begin{array}{c}\text { Control } \\
\text { group }\end{array} \\
\text { Mean } \pm \text { SD }\end{array}$} & \multirow{2}{*}{$\begin{array}{c}t \text { test; } \\
p\end{array}$} \\
\hline & Mean \pm SD & Mean \pm SD & & & & & \\
\hline Fr.2 Hz & $10.1 \pm 1.0$ & $9.9 \pm 0.7$ & 0.40 & Fr. $2 \mathrm{~Hz}$ & $13.4 \pm 1.4$ & $12.4 \pm 1.0$ & $0.005^{* *}$ \\
\hline Fr. $4 \mathrm{~Hz}$ & $10.1 \pm 0.8$ & $9.9 \pm 0.8$ & 0.22 & Fr. $4 \mathrm{~Hz}$ & $13.5 \pm 1.4$ & $12.4 \pm 1.1$ & $0.005^{\text {** }}$ \\
\hline Fr. $6 \mathrm{~Hz}$ & $10.3 \pm 1.2$ & $10.0 \pm 0.9$ & 0.40 & Fr. $6 \mathrm{~Hz}$ & $13.5 \pm 1.4$ & $12.5 \pm 1.1$ & $0.010^{*}$ \\
\hline Fr.9 Hz & $10.1 \pm 0.9$ & $9.9 \pm 1.0$ & 0.51 & Fr.9 Hz & $13.7 \pm 1.4$ & $12.5 \pm 0.9$ & $0.004^{* *}$ \\
\hline$p^{+}$ & 0.38 & $0.029^{*}$ & & $p^{+}$ & 0.27 & $0.002^{* *}$ & \\
\hline
\end{tabular}

$\mathrm{t}$ test: Student $\mathrm{t}$ test

$* \mathrm{p}<0.05 \quad * * \mathrm{p}<0.01$
+ Repeated Measures ANOVA and paired samples test

Fr: Frequency of stimulation 
prolonged CCT values had lesions compatible with the prolongation of CCT (28.5\%) (Table 1).

Nerve conduction studies and needle EMG of all patients and controls were in normal limits. No statistically significant difference existed in comparison of age, body height, sex and arm length between the NB group and the normal group $(\mathrm{p}>0.05)$.

\section{N13 peak latency}

N13 peak latency values of the NB group were statistically higher than the values of the normal group at all stimulation frequencies (for $2 \mathrm{~Hz}, 4 \mathrm{~Hz}$ and $9 \mathrm{~Hz}$ : $\mathrm{p}<0.01$, for $6 \mathrm{~Hz}$ : $\mathrm{p}<0.05$ ) (Table 2).

In the NB group the values of N13 peak latency did not show any statistically significant differences from each other at different stimulation frequencies $(\mathrm{p}>0.05)$ (Table 2).

In the normal group, the values of $\mathrm{N} 13$ peak latency at $9 \mathrm{~Hz}$ stimulation were statistically higher than the values both at $2 \mathrm{~Hz}$ and $4 \mathrm{~Hz}$ stimulations $(\mathrm{p}<0.01$ and $\mathrm{p}<0.05$ respectively). The values of N13 peak latency at other stimulation frequencies did not differ from each other statistically $(\mathrm{p}>0.05)$ (Table 2$)$.

\section{N20 peak latency}

N20 peak latency values of NB group were statistically higher than the values of the normal group at all stimulation frequencies (for $2 \mathrm{~Hz}, 6 \mathrm{~Hz}$ and $9 \mathrm{~Hz}$ : $\mathrm{p}<0.01$, for $4 \mathrm{~Hz} \mathrm{p}<0.05$ ) (Table 3 ).

In the NB group, the values of $\mathrm{N} 20$ peak latency at $6 \mathrm{~Hz}$ stimulation were statistically higher than the values at $2 \mathrm{~Hz}$ $(\mathrm{p}<0.05)$. The same was true for the values at $9 \mathrm{~Hz}$ stimulation when compared with the values at $2 \mathrm{~Hz}(\mathrm{p}<0.01)$. The values of $\mathrm{N} 20$ peak latency at $9 \mathrm{~Hz}$ were higher than the values at $6 \mathrm{~Hz}$ $(p<0.01)$. There were not any statistically meaningful differences between the other comparisons within the same group $(p>0.05)$ (Table 3).

In the normal group, the values of $\mathrm{N} 20$ peak latency at $4 \mathrm{~Hz}$ and $6 \mathrm{~Hz}$ were higher than the values in $2 \mathrm{~Hz}(\mathrm{p}<0.01)$. The values at $9 \mathrm{~Hz}$ were higher than the values at $2 \mathrm{~Hz}(\mathrm{p}<0.01)$. The other comparisons did not show statistically significant changes (p>0.05) (Table 3).

Table 3: Statistical distribution of onset and peak latency values of $\mathrm{N} 20$

\begin{tabular}{|c|c|c|c|c|c|c|c|}
\hline \multirow{2}{*}{$\begin{array}{c}\text { N20 } \\
\text { onset } \\
\text { latency }\end{array}$} & $\begin{array}{l}\text { Patient } \\
\text { group }\end{array}$ & $\begin{array}{l}\text { Control } \\
\text { group }\end{array}$ & \multirow[t]{2}{*}{$t$ test; $p$} & \multirow{2}{*}{$\begin{array}{l}\text { N20 peak } \\
\text { latency }\end{array}$} & \multirow{2}{*}{$\begin{array}{c}\begin{array}{c}\text { Patient } \\
\text { group }\end{array} \\
\text { Mean } \pm \text { SD }\end{array}$} & \multirow{2}{*}{$\begin{array}{c}\begin{array}{c}\text { Control } \\
\text { group }\end{array} \\
\text { Mean } \pm \text { SD }\end{array}$} & \multirow[t]{2}{*}{$t$ test; $p$} \\
\hline & Mean \pm SD & Mean \pm SD & & & & & \\
\hline Fr.2 $\mathrm{Hz}$ & $15.8 \pm 1.5$ & $15.6 \pm 1.1$ & 0.46 & Fr.2 $\mathrm{Hz}$ & $19.0 \pm 1.0$ & $18.2 \pm 1.0$ & $0.004^{* *}$ \\
\hline Fr.4 Hz & $16.6 \pm 1.8$ & $15.5 \pm 1.1$ & $0.017^{*}$ & Fr.4 Hz & $19.4 \pm 1.5$ & $18.4 \pm 1.2$ & $0.016^{*}$ \\
\hline Fr. $6 \mathrm{~Hz}$ & $16.1 \pm 1.5$ & $15.6 \pm 1.2$ & 0.28 & Fr. $6 \mathrm{~Hz}$ & $19.4 \pm 1.1$ & $18.3 \pm 1.1$ & $0.003^{* *}$ \\
\hline Fr.9 Hz & $17.0 \pm 1.6$ & $15.3 \pm 0.6$ & $0.0001^{* *}$ & Fr.9 Hz & $20.0 \pm 1.5$ & $18.1 \pm 0.9$ & $0.0001^{* *}$ \\
\hline$p^{+}$ & $0.004^{* *}$ & $0.001^{\text {** }}$ & & $p^{+}$ & $0.002^{* *}$ & $0.002^{* *}$ & \\
\hline
\end{tabular}

$\mathrm{t}$ test: Student $\mathrm{t}$ test

$* \mathrm{p}<0.05 \quad * * \mathrm{p}<0.01$
+ Repeated Measures ANOVA and

paired samples test

Fr: Frequency of stimulation

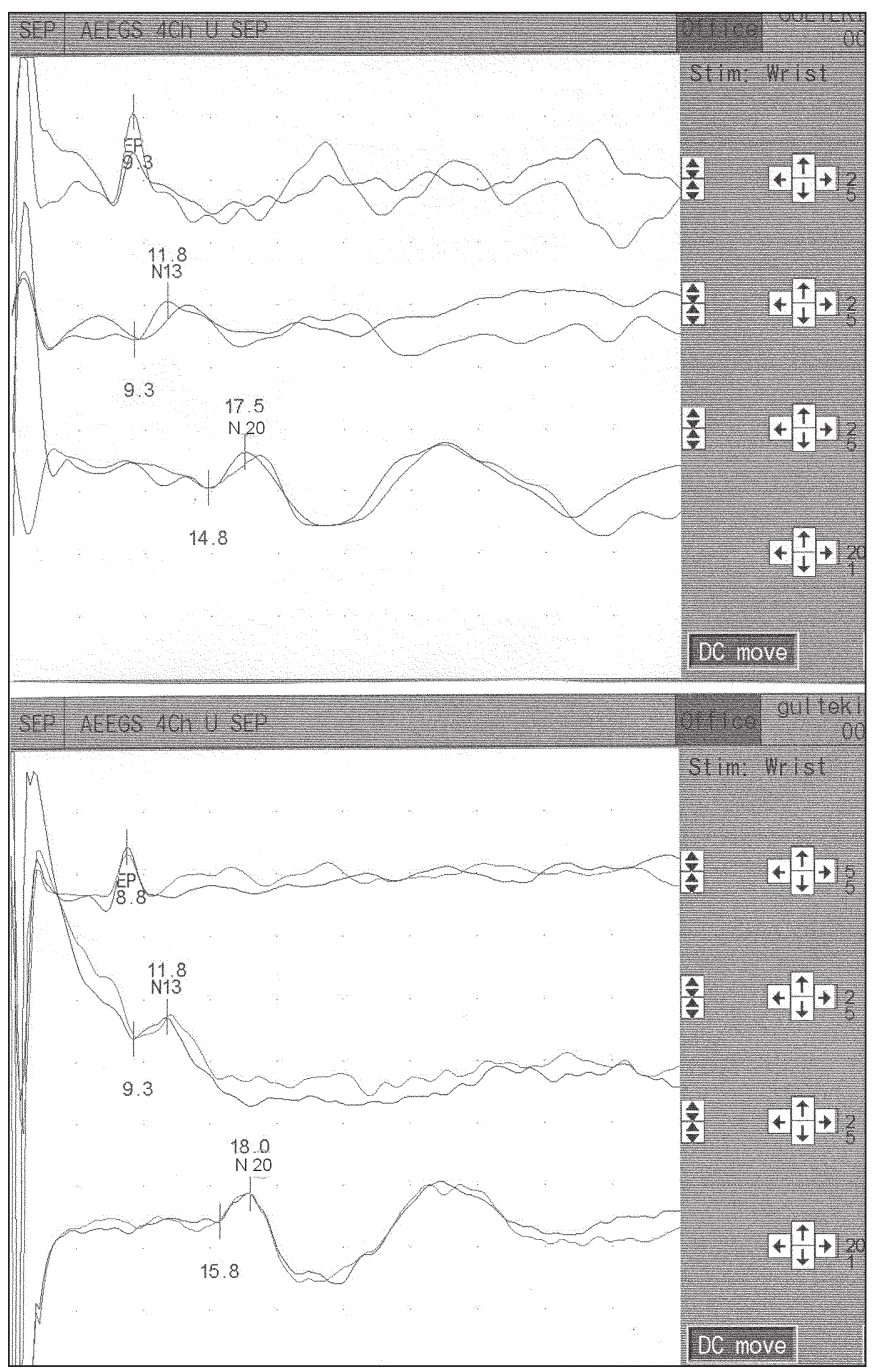

Figure 2: Median nerve SEP recordings of one of our patients showing peak and onset latencies of spinal N13 and cortical N2O potentials. The upper figure shows the recording at $2 \mathrm{~Hz}$ stimulation, peak $C C T=5.7$, onset CCT=5.5. The lower figure shows the recording at $4 \mathrm{~Hz}$ stimulation, peak $C C T=6.2$, onset $C C T=6.5$

\section{N13 onset latency}

The values of N13 onset latency did not show any statistically significant differences between the NB group and the control group ( $>>0.05$ ) (Table 2).

In the NB group, the values of N13 onset latency at different stimulation frequencies did not show statistically meaningful changes when compared with each other ( $p>0.05)$ (Table 2).

In the control group, the values of N13 onset latency at $9 \mathrm{~Hz}$ and $6 \mathrm{~Hz}$ frequencies were statistically higher than the values at $2 \mathrm{~Hz} \quad(\mathrm{p}<0.05)$. There was not any statistically meaningful differences in other comparisons ( $>>0.05)$ (Table 2). 


\section{N20 onset latency}

N20 onset latency values of the NB group were statistically higher than the values of the normal group at $4 \mathrm{~Hz}$ and $9 \mathrm{~Hz}$ stimulations ( $p<0.05$ and $p<0.01$ respectively). The $2 \mathrm{~Hz}$ and $6 \mathrm{~Hz}$ values of the patient and control groups did not show any statistically meaningful changes when compared with each other (Table 3).

In the NB group, the values of N20 onset latency at $4 \mathrm{~Hz}$ and $9 \mathrm{~Hz}$ stimulations were higher than the values at $2 \mathrm{~Hz}$ stimulation $(p<0.05$ and $p<0.01$ respectively). The values at $9 \mathrm{~Hz}$ stimulation were higher than the values at $6 \mathrm{~Hz}$ stimulation $(\mathrm{p}<0.05)$. The other comparisons did not show statistically meaningful changes ( $>0.05)$ (Table 3).

In the control group, the values of $\mathrm{N} 20$ onset latency at $2 \mathrm{~Hz}$ were higher than the values at $4 \mathrm{~Hz}$ and $9 \mathrm{~Hz}(\mathrm{p}<0.05$ and $\mathrm{p}<0.01$ respectively). The values at $6 \mathrm{~Hz}$ were higher than the values at $2 \mathrm{~Hz}(\mathrm{p}<0.01)$. The other comparisons did not show statistically meaningful changes $(\mathrm{p}>0.05)$ (Table 3 ).

\section{Peak central conduction time}

The comparison of peak central conduction time values at all stimulation frequencies did not show any statistically meaningful changes between the NB group and the control group $(\mathrm{p}>0.05)$ (Table 4).

In the NB group, the values of peak central conduction time at $4 \mathrm{~Hz}$ were statistically higher than the values at $2 \mathrm{~Hz}(\mathrm{p}<0.05)$. The same was true for the values at $9 \mathrm{~Hz}$ when compared with the values at $2 \mathrm{~Hz}(\mathrm{p}<0.05)$. The other comparisons did not show statistically meaningful changes ( $p>0.05)$ (Table 4).

In the control group, the values of peak central conduction time at different stimulation frequencies did not show any statistically meaningful changes from each other ( $p>0.05)$ (Table 4).

Table 4: Statistical distribution of onset and peak CCT values

\begin{tabular}{|c|c|c|c|c|c|c|c|}
\hline \multirow[b]{2}{*}{ CCT } & $\begin{array}{l}\text { Patient } \\
\text { group }\end{array}$ & $\begin{array}{l}\text { Control } \\
\text { group }\end{array}$ & \multirow{2}{*}{$\begin{array}{l}\text { t test; } \\
\quad p\end{array}$} & \multirow{2}{*}{$\begin{array}{l}\text { Onset } \\
\mathrm{CCT}\end{array}$} & \multirow{2}{*}{$\begin{array}{c}\begin{array}{c}\text { Patient } \\
\text { group }\end{array} \\
\text { Mean } \pm \text { SD }\end{array}$} & \multirow{2}{*}{$\begin{array}{c}\begin{array}{c}\text { Control } \\
\text { group }\end{array} \\
\text { Mean } \pm \text { SD }\end{array}$} & \multirow{2}{*}{$\begin{array}{c}t \text { test; } \\
\quad p\end{array}$} \\
\hline & Mean \pm SD & Mean \pm SD & & & & & \\
\hline Fr.2 $\mathrm{Hz}$ & $5.5 \pm 1.2$ & $5.8 \pm 0.5$ & 0.33 & Fr.2 $\mathrm{Hz}$ & $5.9 \pm 1.2$ & $5.7 \pm 0.6$ & 0.45 \\
\hline Fr.4 Hz & $6.1 \pm 1.3$ & $5.9 \pm 0.6$ & 0.60 & Fr.4 Hz & $6.6 \pm 2.0$ & $5.7 \pm 0.7$ & $0.023^{*}$ \\
\hline Fr. $6 \mathrm{~Hz}$ & $5.9 \pm 1.1$ & $5.9 \pm 0.5$ & 0.96 & Fr. $6 \mathrm{~Hz}$ & $6.1 \pm 1.2$ & $5.6 \pm 1.0$ & 0.15 \\
\hline Fr.9 Hz & $6.2 \pm 1.4$ & $5.6 \pm 0.6$ & 0.11 & Fr.9 Hz & $6.8 \pm 1.7$ & $5.3 \pm 0.7$ & $0.003^{\text {** }}$ \\
\hline$p^{+}$ & $0.048^{*}$ & 0.16 & & $p^{+}$ & $0.023^{*}$ & 0.48 & \\
\hline
\end{tabular}

$\mathrm{t}$ test: Student $\mathrm{t}$ test

$* \mathrm{p}<0.05 \quad * * \mathrm{p}<0.01$
+ Repeated Measures ANOVA and

paired samples test

Fr: Frequency of stimulation

\section{Onset central conduction time}

The values of onset central conduction time of the NB group were higher than the values of the control group at $4 \mathrm{~Hz}$ and $9 \mathrm{~Hz}$ stimulation frequencies ( $\mathrm{p}<0.05$ and $\mathrm{p}<0.01$ respectively) (Table 4).

In the $\mathrm{NB}$ group, the values at $4 \mathrm{~Hz}$ and $9 \mathrm{~Hz}$ stimulations were higher than the values at $2 \mathrm{~Hz}(\mathrm{p}<0.05)$. The other comparisons were not meaningful statistically $(\mathrm{p}>0.05)$ (Table 4$)$.

In the control group, the values of onset central conduction time at different stimulation frequencies did not show statistically meaningful changes when compared with each other ( $p>0.05$ ) (Table 4).

\section{DiscuSSION}

Somatosensory evoked potentials and the estimation of peak CCT were performed in patients with $\mathrm{NB}$ in several former studies. ${ }^{4,5,11,12}$ However, to our knowledge, the effects of change of stimulation frequencies on SEP parameters have not been studied in this patient group, previously. Onset central conduction time in SEPs of NB patients has not been studied before, either.

We deliberately chose the SEP montage recommended by Mauguière et $\mathrm{al}^{9}$ in this study because the N13 potential is recorded with maximal amplitude using the $\mathrm{Cv}$-AC channel, it is the spinal montage recommended by IFCN (The International Federation of Clinical Neurophysiology in 1999 and to our experience, helps provide more accurate onset and peak latency locations for the N13 potential.

Rizzo et al studied median and peroneal SEPs in two patients with NB, whereas Besana et al studied tibial SEPs in patients with Behcet's disease. Both studies reported pathologic peroneal and tibial SEPs, while median nerve SEPs were normal. None of them discussed central conduction time in the patient groups. ${ }^{10,11}$

Nakamura et al, ${ }^{4}$ studied 17 patients with NB and found that the interpeak latency EP-N13 or N13-N18 of median nerve SEPs were prolonged in $37,7 \%$ of the patients. In median nerve SEPs there were no appreciable prolongation of the interpeak latency EP-N13, however peak central conduction time was significantly prolonged $(p<0.01)$. Onset central conduction time was not assessed in this study, either.

Stigsby et $\mathrm{al}^{5}$ reported that the predominant abnormalities encountered in Behcet's disease were reduced potential amplitudes whereas slowing in conduction was rather mild. Nakamura et $\mathrm{al}^{13}$ supported this distinction for peroneal SEPs though they specifically postulated that slowed median nerve SEP central conduction time and abnormal BAEPs were more common in neuro-Behcet than in multiple sclerosis (MS). However, onset central conduction time was not determined in patients with $\mathrm{NB}$ and therefore the above comparison involved the peak central conduction time only.

In our study, we have measured not only the peak CCT, but also the onset CCT. The results of our study showed that $64 \%$ of our patients had MRI lesions which could have affected CCT. Only $14 \%$ of patients had prolonged peak CCT values while $50 \%$ had prolonged onset CCT values. Three patients who did not have lesions in the somatosensory pathway had prolonged onset CCT values. Thus, our study showed that SEPs and imaging tests could be complementary, not merely confirmatory. Our results also indicated that onset CCT values of the NB group showed 
more pathological values when compared with peak CCT values and that they differed from the values of the normal group.

Studies concerning the changes of stimulus frequencies were performed in normal healthy volunteers before, but to our knowledge, they have not been studied in patient groups. Manzano et $\mathrm{al}^{6}$ stated that increasing the stimulation frequency did not change the peak central conduction time in normals whereas absolute and onset latencies increased. Garcia Larrea et $\mathrm{al}^{14}$ stated that there was no single optimal stimulation rate for SEP recordings and that a combination of different frequencies of stimulation should enhance the diagnostic utility of this technique.

Results of our study showed that peak and onset latencies of $\mathrm{N} 13$ and N20 potentials changed when different stimulation frequencies were applied in the normal controls. The absolute latencies usually increased at higher stimulation frequencies, however the peak central conduction time did not change. This finding overlaps the findings of Manzano et $\mathrm{al}^{6}$ who explained this last finding in terms of fast frequency components (FFC) that were possibly generated in the thalamocortical pathway. They believed that FFC determined the N20 peak in different situations. In our study we also found that onset central conduction time did not change in the normal group when stimulation frequencies were increased. The reason for this observation remains unknown at this time and it is also highly controversial whether the explanation made by Manzano et al is also adaptable to patients with NB who probably may have lesions in the thalamocortical pathway which may not be revealed by conventional imaging studies.

All in all, it is quite obvious that the diagnostic findings of this study may not be very specific for NB. However, using different stimulation frequencies yield some important results referring the physiological dynamics of SEPs. It was suggested that rate effects in SEP recordings of normal people were partly due to selective sensitivity of postexcitatory inhibitory postsynaptic potentials to stimulation frequency. ${ }^{8}$ Diseases affecting the somatosensory pathway may perhaps alter the nature of this selective sensitivity and thus, may produce abnormal changes by exaggerating the influence of these inhibitory effects on SEP parameters in response to higher stimulation frequencies. Hence, this condition may explain why some patients have prolonged absolute latencies and central conduction times when compared with normal people. The differences between impacts of various lesions (e.g demyelination or axonal degeneration) on physiological dynamics of SEPs are hard to suggest, as studies dealing with this subject in different patient groups are very rare.

Our results confirm that the mostly encountered median nerve SEP pathologies in NB patients include the increase in peak latencies of N13 and N20 potentials. Unlike Nakamura et al, we did not find statistically meaningful differences of peak central conduction time between the NB group and the control group and this determination did not change whether we increased the stimulation frequency or not. In this particular aspect, our NB group did not show any statistically meaningful differences from the normal group. However, the statistical evaluation in the NB group showed that the values of peak central conduction at $4 \mathrm{~Hz}$ and $9 \mathrm{~Hz}$ were statistically higher than the values at $2 \mathrm{~Hz}$.

We believe that our most important findings in this study comprise the onset CCT changes in different stimulation frequencies. Our results indicated that the values of onset CCT of the NB group were higher than the values of the control group at $4 \mathrm{~Hz}$ and $9 \mathrm{~Hz}$ stimulation frequencies $(\mathrm{p}<0.05$ and $\mathrm{p}<0.01$ respectively). However, the normal group did not show any changes of onset CCT at higher stimulation frequencies.

Our results may be interpreted that although peak CCT values of the NB group do not differ much from those of normal controls, the statistical differences of onset CCT are meaningful especially when the stimulation frequency is increased as $4 \mathrm{~Hz}$ and $9 \mathrm{~Hz}$.

It is controversial whether onset CCT is correlated with subject height, ${ }^{15,16}$ but values of body height of our patients did not show statistically meaningful differences when compared with the control group. Ozaki et al ${ }^{15,17}$ reported in several of their studies that the "conventional" peak CCT measurement of median nerve SEPs was inadequate and that onset CCT had to be measured also. Tonasaki et $\mathrm{al}^{18}$ reported in another study that the peak CCT was more affected by aging than the onset CCT. Therefore, they concluded that the onset CCT measurement was preferable to the peak CCT measurement when assessing the central somatosensory conduction. However, to our knowledge, onset CCT measurements have not been studied in most of the patient groups with prolongation of peak central conduction times. Our main concern to design this study was to observe the changes in central conduction time in patients with NB when the stimulation frequencies were increased. Both Nakamura et $\mathrm{al}^{4}$ and Stigsby et $\mathrm{al}^{5}$ implied that the diagnostic utility of central conduction time in neuro-Behcet patients was not as efficient as its utility in multiple sclerosis patients who showed prominent prolongation of central conduction time.

While performing our study, we wondered whether our results would help to find a more convenient usage of median nerve SEPs in neuro-Behcet patients in whom the prolongation of CCT seemed less prominent than the MS group in former studies. Now we believe that our results favour the usage of onset CCT along with peak CCT over the usage of peak CCT alone. We also conclude that a design of median nerve SEP study that comprises onset CCT measurements at higher stimulation frequencies may be more helpful to diagnose the pathologies of central conduction time in neuro-Behcet's disease.

\section{ACKNOWLEDGEMENT}

We sincerely thank Levent Gungor, MD. for the construction of Figure 1.

\section{REFERENCES}

1. Siva A, Altintas A, Saip S. Behcet's syndrome and the nervous system. Curr Opin Neurol. 2004;17:347-57.

2. Akman-Demir G, Serdaroglu P, Tasci B. Clinical patterns of neurological involvement in Behcet's disease: evaluation of 200 patients. The Neuro-Behcet Study Group. Brain. 1999;122:2171-82.

3. Al-Kawi MZ. Neuro-Behcet disease: a review. J Trop Geograph Neurol. 1992;2:49-56.

4. Nakamura Y, Takahashi M, Kitaguchi M, Imaoka H, Tarui S. Brainstem auditory and somatosensory evoked potentials in Neuro-Behcet's syndrome. Jpn J Psychiatry Neurol. 1989;43:191-200.

5. Stigsby B, Bohlega S, Al-Kawi MZ, Al-Dalaan A, El- Ramahi K. Evoked potential findings in Behcet's Disease. Brainstem auditory, visual and somatosensory evoked potentials in 44 patients. Electroencephalogr Clin Neurophysiol. 1994;92:273-81. 
6. Manzano GM, De Navarro JM, Nobrega JA, Novo NF, Juliano Y. Short latency median nerve somatosensory evoked potential (SEP): increase in stimulation frequency from 3-30 $\mathrm{Hz}$. Electroencephalogr Clin Neurophysiol. 1995;96:229-35.

7. Delberghe X, Mavroudakis N, Zegers de Beyl D, Brunko E. The effect of stimulus frequency on post and precentral short latency somatosensory evoked potentials (SEP). Electroencephalogr Clin Neurophysiol. 1990;77:86-92.

8. Huttunen J, Homberg V. Influence of stimulus repetition rate on cortical somatosensory potentials evoked by median nerve stimulation: implications for generation of mechanisms. J Neurol Sci. 1991;105:37-43.

9. Mauguière F, Allison T, Babiloni C, Buchner H, Eisen AA, Goodin DS et al. Somatosensory evoked potentials. Electroencephalogr Clin Neurophysiol. 1999;:Suppl 52:S79-90.

10. Criteria for diagnosis of Behcet's disease. International Study Group for Behcet's disease. Lancet. 1990;335:1078-80.

11. Besana C, Comi G, Del Maschio A, Praderio L, Vergani A, Medaglini $\mathrm{S}$ et al. Electrophysiological and MRI evaluation of neurological involvement in Behcet's disease. J Neurol Neurosurg Psychiatry. 1989;52 (6):749-54.

12. Rizzo PA, Valle E, Mollica MA, Sanarelli L, Pozzessere G. Multimodal evoked potentials in neuro-Behcet: a longitudinal study of two cases. Acta Neurol Scand. 1989;79 (1):18-22.
13. Nakamura Y, Takahashi M, Kitaguchi M, Imaoka H, Taruis S. Comparative study of evoked potentials in multiple sclerosis and neuro-Behcet's syndrome. Electromyogr Clin Neurophysiol. 1989;29:59-64.

14. Garcia Larrea L, Bastuji H, Mauguière F. Unmasking of cortical SEP components by changes in stimulus rate: a topographic study. Electroencephalogr Clin Neurophysiol. 1992;84:71-83.

15. Ozaki I, Takada H, Baba M, Matsunaga M. Correlation of somatosensory central conduction time with height. Neurology. 1994;44 (6):1115-9.

16. Zegers de Beyl D, Delberghe X, Herbaut AG, Brunko E. The somatosensory central conduction time: physiological considerations and normative data. Electroencephalogr Clin Neurophysiol. 1998;71 (1):17-26.

17. Ozaki I, Takada H, Shimamura H, Baba M, Matsunaga M. Central conduction in somatosensory evoked potentials: comparison of ulnar and median data and evaluation of onset versus peak methods. Neurology. 1996;47 (5):1299-304.

18. Tanosaki M, Ozaki I, Shimamura H, Baba M, Matsunaga M. Effects of aging on central conduction in somatosensory evoked potentials: evaluation of onset versus peak methods. Clin Neurophysiol. 1999;110 (12):2094-103. 